\title{
The Influence of Perceived Organizational Support and Proactive Personality on Organizational Commitment and Organizational Citizenship Behavior Among Banking Employees in Malang
}

\author{
Arina Idzna*, Kusdi Raharjo, Tri Wulida Afrianty \\ Department of Business Administration \\ University of Brawijaya \\ Malang, Indonesia \\ *arinaidzna@student.ub.ac.id, kusdi@ub.ac.id,twulidafia@ub.ac.id
}

\begin{abstract}
In current banking industry competition, not only support from the organization are needed by employees to increase commitment and organizational citizenship behaviour (OCB), but also the employees' personality itself are important. Using social exchange theory, this research aims to determine the effect of organizational support (POS) and proactive personality on commitment and OCB. Quantitative explanatory approach and Partial Least Square Structural Equation Modelling (PLSSEM) are used in this research. Questionnaires collected from 92 samples of Bank Negara Indonesia (BNI) permanent staffs in Malang. Using SmartPLS 3.0, the result of this research show that POS is a significant predictor of employees' organizational commitment. On the other hand, proactive personality insignificantly affects the employees' organizational commitment, but significantly affect employees' OCB. This research also shows that only employees' organizational commitment that are successfully mediate the relationship of POS and OCB.
\end{abstract}

Keywords-social exchange theory (SET), perceived organizational support (POS), proactive pesonality, organizational commitment, organizational citizenship behavior $(\mathrm{OCB})$

\section{INTRODUCTION}

In digital banking era 4.0 organizational commitment become crucial for the companies due to the rapid growth of financial technology (fintech) and the increasing level of competition. It is essential for the companies to encourage their employee's organizational commitment because employees play important role in every part of the organization to carry out the objectives in resulting competitive advantage. Conversely, according to the data from Towers Watson Indonesia in 2014, bank companies have poor statistics in maintain their human resources [1]. Survey result by PricewaterhouseCoopers (PwC) Indonesia in 2014 reveal that the turnover rate in this sector reached $15 \%$ [2]. Furthermore, survey conducted by Mercer Talent Consulting \& Information Solution in 2015 found turnover rate in this sector was $16 \%$, the highest rate compared to other industrial sectors in Indonesia [1].

High turnover rate indicates that employee's organizational commitment is low, as "organizational commitment" referred to a strong desire to remain in a certain organization, and acceptance of the organizational values and goals [3]. Many critical variables that encourage employees' organizational commitment e.g., external, and internal variables. Perceived organizational support (POS) as an external variable play an important role to make employees stay in organization and work in full capacity as an organizational member [4]. The high level of organizational support will enhance a feeling of employee to carry out the best effort on duties, not only because they feel they have to, but also obliged to repay the support from organization by showing positive attitude towards the organization [5]. A number of empirical studies have also proven the relationship between POS and organizational commitment $[4,6,7]$

In order to be an effective and successful organization, employees have to dedicate their maximum attention, time, and passion to the organization beyond their formal job requirement. This behaviour refers to organizational citizenship behaviour (OCB) [8]. Employees with OCB will show some attitudes e.g., help each other in the workplace, working overtime without extra pay, complying informal codes of conduct [6], volunteering for additional work and avoiding unnecessary conflicts [9]. Several previous studies reveal that OCB is the result of organizational commitment and POS Researchers found a significant correlation between these two variables [10,11]. Employees who are committed to their organization tend to show OCB compared to those who are not committed [12].

Social exchange theory (SET) explains that every interaction between individuals is a form of resource exchange [13]. In this study, SET is used to explain the relationship 
between POS, organizational commitment, and OCB. The basic assumption of SET is that the parties involved will mutually enhance good relationship in hope it will benefit them in the future [13]. Social exchange theorists assumed "job" as a form of "exchange" between effort and loyalty for social benefits and rewards [8]. Supported by reciprocal norms on SET, if organization supports their employees (beyond employees' expectation), employees will give reciprocity by committed to the organization, work beyond their formal job requirements, and more willing to retain their membership in the organization.

Previous studies largely focus on analysing variable that encourage organizational commitment and OCB from external factors $[6,7,12]$. Just a few of previous studies that consider internal factors, such as personal factors, on increasing employees' organizational commitment. However, beside support from organization, employees' personality itself are important to enhance organizational commitment and OCB. Proactive personality as an internal variable play an important role in it as a proactive individual are able to identify opportunities and do appropriate actions to take advantage of these opportunities, show initiative until significant changes occur [14]. Employees with a high level of proactive personality found to have a high level of organizational commitment as well [15]. Some studies reveal that proactive personality affect the organizational commitment [16] and has the strongest predictive value for OCB than other personality factors $[17,18]$. Therefore, there is a gap in existing literature that will be filled by analysing the effect of proactive personality on organizational commitment and OCB. But the other influence of personality also taken into account, considering that the level of proactivity also depends on employee autonomy and the responsibility they have.

This research was conducted in Bank Negara Indonesia (BNI) Regional Office Malang, where the turnover rate is $15.7 \%$, which is the highest rate among others State-Owned Banks in Malang [19]. The ideally turnover rate of banking industry should be only $5 \%$ to keep confidentiality of customer data [1]. The low rate of organizational commitment that lead to turnover can disrupt the company's operational stability. Due to the limited studies that consider personality factors, this research will give insight to the factors that encourage commitment and OCB, both from external and internal variable. Therefore, this research aims to analysing the influence of POS and proactive personality on organizational commitment and OCB.

\section{METHOD}

This research is an explanatory research with quantitative approach that conducted in Bank Negara Indonesia (BNI) Malang. Saturated technique sampling used in this research to collected questionnaire from 92 permanent staffs of BNI Malang. The respondents' average age is between $26-35$ with 4 years average work experience. Most of them were bachelor holders, which $55,4 \%$ are female and $44,5 \%$ are male.

\section{A. Research Hypothesis}

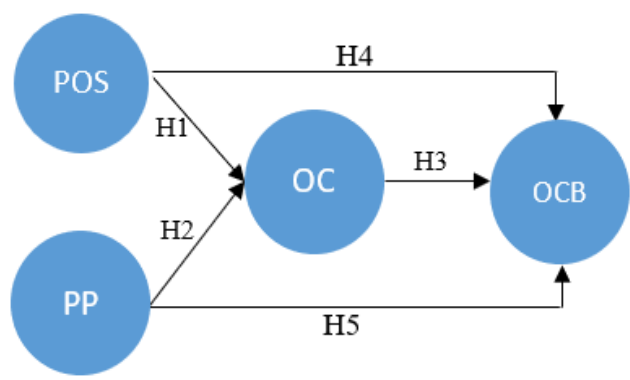

Fig. 1. Hypothesis model.

According to Figure 1, the research hypothesis are as follow:

H1: There is an influence of perceived organizational support on organizational commitment.

H2: There is an influence of proactive personality on organizational commitment.

H3: There is an influence of organizational commitment on organizational citizenship behaviour.

H4: There is an influence of perceived organizational support on organizational citizenship behaviour.

H5: There is an influence of proactive personality on organizational citizenship behaviour.

\section{B. Measurements}

This research use Likert five-point scale which (5) refers to "strongly agree" and (1) refers to "strongly disagree". POS variable use Survey of Perceived organizational Support (SPOS) short version as the measurement, which developed by Eisenberger et al. with total 8 items [20]. Proactive personality dimensions refer to Parker and Collins literature [21], while the items adapted Searle's questionnaire regarding proactive personality and proactive work behaviour [22]. Organizational commitment measure by Allen Meyer Organizational Commitment Scale with 18 items in total [23]. OCB measurement refers to OCB scale by Podsakoff et al. [24] while the items adapted questionnaire by Prasetio [25].

\section{Evaluation of Measurement Model (Outer Model)}

The validity test was calculated in two stages. The first stage, all items will be tested, then items that have loading factor value $<0.7$ must be removed from the construct. Then the second phase of validity test was calculated as presented in Table 1. While the reliability determined from composite reliability value and average variance extracted (AVE) value. The construct is reliable if the composite reliability value > 0.70 and the AVE value is at least 0.5. According to Table 2, the composite reliability value for each variable as follow: POS $=0.882 ;$ proactive personality $=0.910 ;$ organizational commitment $=0.870$; and $\mathrm{OCB}=0.919$ with $\mathrm{AVE}$ value $>0.5$. It can be concluded that the instrument is reliable. 
TABLE I. OUTER LOADING CONVERGENT VALIDITY

\begin{tabular}{|c|c|c|c|c|}
\hline \multirow{2}{*}{ Variable } & \multirow{2}{*}{ Indicator } & \multirow{2}{*}{ Item } & \multicolumn{2}{|c|}{ LF $>0.7$ = Valid } \\
\hline & & & $L F$ & Info \\
\hline \multirow{4}{*}{$\begin{array}{l}\text { Perceived } \\
\text { Organizational } \\
\text { Support }\end{array}$} & \multirow{4}{*}{ POS } & POS1 & 0.826 & Valid \\
\hline & & POS4 & 0.791 & Valid \\
\hline & & POS6 & 0.763 & Valid \\
\hline & & POS8 & 0.844 & Valid \\
\hline \multirow{6}{*}{$\begin{array}{l}\text { Proactive } \\
\text { Personality }\end{array}$} & $\begin{array}{l}\text { Taking } \\
\text { charge }\end{array}$ & TC3 & 0.789 & Valid \\
\hline & \multirow{3}{*}{ Voice } & $\mathrm{VC} 1$ & 0.858 & Valid \\
\hline & & VC3 & 0.820 & Valid \\
\hline & & VC4 & 0.800 & Valid \\
\hline & \multirow{2}{*}{$\begin{array}{l}\text { Problem } \\
\text { Prevention }\end{array}$} & PP2 & 0.737 & Valid \\
\hline & & PP3 & 0.743 & Valid \\
\hline \multirow{5}{*}{$\begin{array}{l}\text { Organizational } \\
\text { Commitment }\end{array}$} & $\begin{array}{l}\text { Affective } \\
\text { commitment }\end{array}$ & $\mathrm{AC} 1$ & 0.718 & Valid \\
\hline & \multirow{2}{*}{$\begin{array}{l}\text { Continuance } \\
\text { commitment }\end{array}$} & $\mathrm{CC} 2$ & 0.722 & Valid \\
\hline & & CC6 & 0.742 & Valid \\
\hline & $\begin{array}{l}\text { Normative } \\
\text { commitment }\end{array}$ & $\mathrm{NC} 3$ & 0.802 & Valid \\
\hline & & $\mathrm{NC4}$ & 0.795 & Valid \\
\hline \multirow{7}{*}{$\begin{array}{l}\text { Organizational } \\
\text { Citizenship } \\
\text { Behavior }\end{array}$} & \multirow{3}{*}{ Altruism } & AT1 & 0.803 & Valid \\
\hline & & AT2 & 0.770 & Valid \\
\hline & & AT3 & 0.849 & Valid \\
\hline & \multirow{2}{*}{ Coutersy } & CT1 & 0.760 & Valid \\
\hline & & CT2 & 0.808 & Valid \\
\hline & \multirow{2}{*}{ Civic virtue } & CV1 & 0.787 & Valid \\
\hline & & CV2 & 0.721 & Valid \\
\hline
\end{tabular}

TABLE II. COMPOSITE RELIABILITY AND AVE

\begin{tabular}{|l|l|l|}
\hline \multicolumn{1}{|c|}{ Variable and Indicator } & $\begin{array}{c}\text { Composite } \\
\text { Reliability }\end{array}$ & AVE \\
\hline Perceived Organizational Support & 0.882 & 0.651 \\
\hline Proactive Personality & 0.910 & 0.628 \\
\hline Taking Charge & 0.793 & 0.561 \\
\hline Voice & 0.898 & 0.746 \\
\hline Individual Innovation & 0.860 & 0.672 \\
\hline Problem Prevention & 0.824 & 0.701 \\
\hline Organizational Commitment & 0.870 & 0.573 \\
\hline Affective Commitment & 0.871 & 0.695 \\
\hline Continuance Commitment & 0.880 & 0.648 \\
\hline Normative Commitment & 0.860 & 0.674 \\
\hline $\begin{array}{l}\text { Organizational Citizenship } \\
\text { Behaviour }\end{array}$ & 0.919 & 0.618 \\
\hline Altruism & 0.928 & 0.812 \\
\hline Contentiousness & 0.878 & 0.707 \\
\hline Sportsmanship & 0.837 & 0.720 \\
\hline Courtesy & 0.912 & 0.776 \\
\hline Civic Virtue & 0.901 & 0.751 \\
\hline
\end{tabular}

\section{RESULTS}

Based on the hypothesis test result on Table 3, the following results are obtained:

- Test result for H1 reveal that the path coefficient of POS on organizational commitment is 0.512 , the t-test value is 5.458 and a $\mathrm{P}$-value of 0.000 . The $\mathrm{t}$-count value is greater than the $\mathrm{t}$-table $(\mathrm{t}$-table $=1.960)$ and the $\mathrm{P}$ value is less than 0.05 . This result means that POS has a significant effect on employees' organizational commitment, so $\mathrm{H} 1$ was accepted.

- Test result for H2 show that the path coefficient of proactive personality on organizational commitment is 0.196 , the t-test value is $1.582<\mathrm{t}$-tabel and P-value of $0.114>0.05$. This result show that proactive personality has a non-significant effect on organizational commitment, so $\mathrm{H} 2$ hypothesis was rejected.

- Test result for $\mathrm{H} 3$ reveal that the path coefficient of organizational commitment on OCB is 0.345 , the $\mathrm{t}$-test value is $4.329>\mathrm{t}$-table and $\mathrm{P}$-value of $0.000>0.05$. This result means that organizational commitment has a significant effect on OCB, so H3 was accepted.

- Test result for $\mathrm{H} 4$ reveal that the path coefficient of POS on OCB is 0.196 , the $\mathrm{t}$-test value is $1.582<\mathrm{t}$-table and P-value of $0.114>0.05$. This result means that POS has a non-significant effect on the $\mathrm{OCB}$, so $\mathrm{H} 4$ was rejected.

- Test result for H1 reveal that the path coefficient of proactive personality on OCB is 0.516 , the t-test value is $6.657>\mathrm{t}$-table and a $\mathrm{P}$-value of $0.000<0.05$. This result means that proactive personality has a significant effect on the OCB, so H5 was accepted.

TABLE III. RESULT OF HYPOTHESIS TESTING

\begin{tabular}{|l|l|l|l|l|}
\hline \multicolumn{1}{|c|}{ Variable } & $\begin{array}{c}\text { Original } \\
\text { Sample } \\
(\mathbf{O})\end{array}$ & \multicolumn{1}{|c|}{$\begin{array}{c}\text { T } \\
\text { statistics }\end{array}$} & P-values & Result \\
\hline $\begin{array}{l}\text { POS > OC } \\
\text { (H1) }\end{array}$ & 0.512 & 5.458 & 0.000 & Accepted \\
\hline $\begin{array}{l}\text { OC }>\text { OCB } \\
\text { (H3) }\end{array}$ & 0.345 & 4.329 & 0.000 & Accepted \\
\hline $\begin{array}{l}\text { PP -> OCB } \\
\text { (H5) }\end{array}$ & 0.516 & 6.657 & 0.000 & Accepted \\
\hline PP -> OC (H2) & 0.196 & 1.582 & 0.114 & Rejected \\
\hline $\begin{array}{l}\text { POS -> OCB } \\
\text { (H4) }\end{array}$ & 0,176 & 1.613 & 0.107 & Rejected \\
\hline
\end{tabular}

\section{DISCUSSION}

This research was analysed external (POS) and internal (proactive personality) variable in influencing employees' organizational commitment and OCB. The major finding of this research show that POS has a greater influence on organizational commitment rather than proactive personality (H1 accepted and $\mathrm{H} 2$ rejected). This result is consistent with the social exchange theory and some previous studies i.e., study by Muhammad, Gunduz, and Sherwani $[4,6,26]$. This means that if organization support and value their employees, they tend to be committed to the organization and more likely to stay as a member of organization [27]. Rhoades and Eisenberger also stated that the high level of organizational support will create a feeling of employees to fulfil their obligations, not only because they have to, but also reciprocate by showing positives attitude towards organizational goals [5]. 
Due to the limited studies that considered personality factors as organizational commitment and OCB antecedent, there is a gap in existing literature that will be filled by analysing the effect of proactive personality on organizational commitment and OCB. The result found that proactive personality has a significant influence on OCB (H5 accepted). Among all antecedents of OCB in this research, proactive personality has a greatest influence on OCB rather than organizational commitment and POS (H3 accepted but $\mathrm{H} 4$ rejected). This means that individual with high level of proactivity tend to work beyond the formal job requirements. In accordance with this finding, Gan and Cheung found that employees with proactive personality are more motivated to take initiatives to contribute to the organization and increase their willingness to be involved in OCB [28]. Another study by Podsakoff et al. institute that individual with high proactive personality tend to show OCB as well as other personality traits associated with OCB [29].

Proactive personality found to be non-significantly affect organizational commitment. This result is contradicting with the study conducted by Joo and Bennett [15] and Gudermann [27] who found that proactive personality positively affects organizational commitment, especially affective commitment. This contradiction might be caused by the difference of the research location. Joo and Bennett conducted study in a privately owned enterprise, while this research conducted in a state-owned bank. In fact, the level of proactivity is highly corelated on employee autonomy [15]. Compared to privately owned enterprises, the level of employee autonomy in stateowned enterprise is less efficient in carrying out their business activities due to political interference [30].

Organizational commitment found to be significantly affect OCB. If organizational members are committed and loyal to their organization, they tend to show extra role behaviour by working more than what is specified in their job descriptions. Organizational commitment also success to mediates the relationship between POS and OCB. This become interesting because the direct effect of POS on OCB was not significant, but after mediate with organizational commitment, it becomes significant. This result indicates that if company want to increase the level of employees' OCB through POS, the first step to be taken is improving employees' commitment towards organization.

\section{CONCLUSION}

Supported by previous research, this study found that to encourage organizational commitment among employees, the essential variable is support from the organization. Another finding suggests that proactive personality has the greatest effect on OCB rather than organizational commitment and POS. The main limitation of this research was the data only gathered in a single organization using a single collection tool and in a single cultural setting (Asia/Indonesia). While hypotheses were built mainly using Western-based literature. This lead to some of the results were consistent with the predictions based on previous Western studies, and the rest is not. The authors recommend that the future research should study multiple companies and more varied respondents in general. In addition, future research also can build the hypothesis in another cultural setting literature.

Due to limited studies that consider personality rather than organizational factors in increasing commitment and OCB, this research will give insight to the influence of $\mathrm{POS}$ and proactive personality on organizational commitment and OCB. For the organization, they responsible to create POS that increase organizational commitment and find the suitable employees with the right characteristic of proactivity. Moreover, companies need to enhance hiring process in organization by developing methods to identify employees with proactive personality and keep going with the existing process of organizational support. We hope that this research can pave the way for future research and give empirical support for management practice.

\section{REFERENCES}

[1] N.A.T.M. Dewi, N.M.S. Wulanyani, "Pengaruh kepuasan kerja dan konflik peran terhadap intensi turnover pada karyawan bank di Denpasar”, Jurnal Psikologi Udayana, Vol.4, No.2, 399-412, 2017.

[2] P.W.C. "Indonesian banking survey 2014". 2014 https://www.pwc.com/id/en/publications/assets/indonesian-bankingsurvey-2014.pdf.

[3] R.T. Mowday, L.W. Porter, R. Steers, "Organizational linkages: The psychology of commitment, absenteeism, and turnover", California: Academic Press, San Diego, 1982.

[4] Y. Gunduz, "The effect of organizational support on organizational commitment", The Antropologist, Vol. 18, Issue 3, pp. 1041-1057, 2014.

[5] L. Rhoades, R. Eisenberger, "Perceived organizational support: A review of literature", Journal of Applied Psychology, Vol. 87, pp. 698714, 2002.

[6] A.H. Muhammad, "Perceived organizational support on organizational citizenship behavior: The case of kuwait", International Journal of Business Administration, Vol. 5 No. 3, 2014.

[7] N. Arshadi, "The relationships of perceived organizational support (POS) with organizational commitment, in-role performance, and turnover intention: mediating role of felt obligation", Social and Behavioral Sciences, 30: 1103-1108, 2011

[8] T.S. Bateman, D.W. Organ, "Job satisfaction and the good soldier: the relationship between affect and employee citizenship", Academic and Management Journal, Vol 26, pp. 587-595, 2000.

[9] D. Mageshkumar, "Influence of perceived organizational support, organizational commitment on organizational citizenship behavior among marketing executives", The International Journal of Indian Psychology, Vol. 4, Issue 1, pp.2349-3429, 2016.

[10] R. Bogler, A. Somech, "Influence of teacher empowerment on teachers organizational commitment, professional commitment and organizational citizenship behavior in schools", Teaching and Teacher Education, Vol. 20, pp. 277-289, 2004

[11] S. Nguni, P. Sleegers, E. Denessen, "Transformational and transactiona leadership effects on teachers' job satisfaction, organizational commitment, and organizational citizenship behavior in primary schools:Tthe tanzanian case", School Effectiveness and School Improvement, Vol. 17, Issue 2, 145-177, 2006

[12] M. Nadim, M.H. Hasan, S. Abbas, A. Naveed, "The role of organizational commitment and perceived organizational support in promoting organizational citizenship behavior", International Journal of Social Science, Vol. 2, Issue 3, pp. 54-67, 2016. 
[13] G.C. Homans, "Social behavior as exchange", American Journal of Sociology, Vol. 63, pp. 597-606, 1958.

[14] S.E. Seibert, M.L. Kraimer, M.J. Crant, "What do proactive people do? A longitudinal model linking proactive personality and career success", Personnel Psychology, Vol 54, Issue 4, pp. 845-874, 2001.

[15] B.K. Joo, R.H. Bennett, "The influence of proactivity on creative behavior, organizational commitment, and job performance: Evidence from a korean multinational firm", Journal of International \& Interdisciplinary Business Research, Vol. 5, 2018

[16] D.A. Major, J.M. Holland, K.L. Oborn, "The influence of proactive personality and coping on commitment to stem majors", The Career Development Quarterly, Vol. 60, pp. 16-24, 2012.

[17] M.J. Crant, "The proactive personality scale and objective job performance among real estate agents", Journal of Applied Psychology, Vol. 80, Issue 4, pp. 532-537, 1995.

[18] S. Eisenberger, R. Huntington, S. Hutchnison, D. Sowa, "Perceived organizational support”, Journal of Applied Psychology, Vol. 71, pp. 500-507, 1986.

[19] H. Hardy, "Pengaruh employer branding terhadap employee engagement, employee expectation dan discretionary effort", Thesis Magister Administrasi Bisnis, Fakultas Ilmu Administrasi, Universitas Brawijaya, 2019. Unpublish.

[20] J.A. Thompson, "Proactive personality and job performance: A social capital perspective", Journal of Applied Psychology, Vol. 90, Issue 5, pp. 1011-1017, 2005.

[21] S.K. Parker, CG. Collins, Taking stock: Integrating and differentiating multiple proactive behaviors", Journal of Management, Vol. 36, Issue 3, pp. 633-662, 2010.
[22] T.P. Searle, "A multilevel examination of proactive work behaviors: Contextual and individual differences as antecedents", Thesis, Dissertations, \& Student Scholarship: Agricultural Leadership, Education \& Communication Department. Paper 20, 2011.

[23] N.J. Allen, J.P. .Meyer, "Affective, continuance and normative commitment to the organization: An examination of construct validity", Journal of Vocational Behavior, Vol. 49, pp. 252-276, 1996.

[24] P.M. Podsakoff, S.B. MacKenzie, R.H. Moorman, R. Fetter, "Transformational leader behaviors and their effects on followers' trust in leader, satisfaction, and organizational citizenship behaviors", The Leadership Quarterly, Vol. 1, Issue 2, pp. 107-142, 1990.

[25] A.P. Prasetio, "Pengaruh work-life balance terhadap organizational citizenship behavior", Disertasi Program Doktor Ilmu Manajemen Universitas Pendidikan Indonesia, 2016. Unpiublished.

[26] K.H. Sherwani. "The effect of perceived organizational support on employee's organizational commitment and employee behavior. The case of a construction company in erbil city, kurdistan region", International Journal of Innovative Technology and Exploring Engineering (IJITEE), ISSN: 2278-3075, Volume-8, Issue-93, 2019.

[27] M. Gudermann, "The relationship between proactive personality, affective commitment and the role of job stressors", Enschede: Belanda. University of Twente. "Bachelor Thesis", 2010.

[28] Y. Gan, F.M. Cheung, "From proactive personality to organizational citizenship behavior: mediating role of harmony", Psychological Reports, Vol. 106, Issue 3, pp. 755-765, 2010.

[29] P.M. Podsakoff, S.B. MacKenzie, J.B. Paine, D.G. Bachrach, "Organizational citizenship behaviors: A critical review of the theoretical and empirical literature and suggestions for future research", Journal of Management, Vol. 26, No. 3, 513-563, 2000.

[30] Shleifer, Andrei, WV. Robert, "Politicians and firms", Quarterly Journal of Economics, Vol. 109, Issue 4, pp. 995-1025, 1994. 